Jurnal Basicedu Volume 4 Nomor 1 Tahun 2020 Halaman 210 - 220

JURNAL BASICEDU

Research \& Learning in Elementary Education

https://jbasic.org/index.php/basicedu

\title{
PEMAHAMAN KONSEP GURU DAN CALON GURU TENTANG INTEGRASI SAINS- ISLAM PADA MATERI REPRODUKSI PADA TUMBUHAN
}

\author{
Rafika Elsa Oktaviani ${ }^{1}$, Zarkasih $^{2}$, Rian Vebrianto ${ }^{3}$ \\ Magister Pendidikan Guru Madrasah Ibtidaiyah, Tarbiyah dan Keguruan \\ Universitas Islam Negeri Sultan Syarif Kasim Riau \\ Email : rafikaelsaoktaviani@gmail.com ${ }^{1}$, zarkasih@uin-suska.ac.id ${ }^{2}$, ${\text { rian.vebrianto@uin-suska.ac.id }{ }^{3}}^{2}$
}

\begin{abstract}
Abstrak
Penguasaan konsep merupakan bagian yang sangat penting yang harus dimiliki oleh guru dan calon guru ketika mempelajari sains. Salah satu materi IPA adalah reproduksi pada tumbuhan. Penelitian ini bertujuan untuk menganalisis pemahaman konsep Integrasi (Sains-Islam) reproduksi tumbuhan pada Guru dan calon guru. Harapannya dengan adanya integrasi tersebut memudahkan siswa untuk menambah wawasan serta munculnya keyakinan ilahiyyah. Sehingga telihat jelas bahwa ilmu-ilmu sains dengan ilmu agama saling melengkapi. Jenis penelitian ini adalah survey Subyek dalam penelitian ini adalah guru SD dan mahasiswa semester II TA 2018/2019 yang berjumlah 30 responden. Penelitian ini menggunakan angket skala likert. Nilai rata-rata hasil quesioner secara keseluruhan yaitu 3,7, sebesar 73,4\%, pemahaman konsep guru dan calon guru pada konsep sains-islam reproduksi pada tumbuhan kategorinya tinggi. hasil perhitungan akhir rata-rata pemahaman konsep setelah diberikan pernyataan dalam bentuk angket pemahaman konsep sains reproduksi pada tumbuhan sebesar 74,9\% dengan kategori tinggi. Sedangkan pemahaman konsep Islamnya sebesar $69 \%$ dengan kategori sedang. Secara umum persentase pemahaman guru dan calon guru pada konsep sains lebih besar (74,9\%) dari pada konsep islam (69\%). Sehingga dapat diketahui pemahaman guru dan calon guru tentang konsep reproduksi tumbuhan secara sains lebih baik dari pada konsep reproduksi tumbuhan secara islam.
\end{abstract}

Kata kunci: Pemahaman, konsep, Reproduksi, tumbuhan

\begin{abstract}
Mastery of concepts is a very important part that teachers and prospective teachers must have when learning science. One of the science materials is reproduction in plants. This study aims to analyze the understanding of the concept of Integration (Science-Islam) of plant reproduction in Teachers and prospective teachers. The hope with the integration is to facilitate students to add insight and the emergence of divine beliefs. So it seems clear that the sciences with the science of religion complement each other. This type of research is a survey Subjects in this study were elementary school teachers and second semester students of the 2018/2019 academic year, totaling 30 respondents. This study uses a Likert scale questionnaire. The overall value of the questionnaire results is 3.7, at 73.4\%, understanding the concept of teachers and prospective teachers in the concept of reproductive sciences in plants is categorized as high. the results of the final calculation of the average understanding of the concept after being given a statement in the form of a questionnaire understanding of reproductive science concepts in plants by $74.9 \%$ with a high category. While the understanding of the Islamic concept is $69 \%$ with the medium category. In general the percentage of teachers and prospective teachers' understanding of the science concept is greater (74.9\%) than the Islamic concept (69\%). So that it can be seen that the understanding of teachers and prospective teachers about the concept of plant reproduction is better than the concept of plant reproduction Islam.
\end{abstract}

Keyword: Realistic Understanding, concepts, reproduction, plants

@ Jurnal Basicedu Prodi PGSD FIP UPTT 2019

$\triangle$ Corresponding author :

Address : Jalan Wonosari, Pekanbaru, Riau

Email : rafikaelsaoktaviani@gmail.com

Phone : 085264304252 
211 Pemahaman Konsep Guru Dan Calon Guru Tentang Integrasi Sains-Islam pada Materi Reproduksi pada Tumbuhan - Rafika Elsa Oktaviani, Zarkasih dan Rian Vebrianto

\section{PENDAHULUAN}

Mengajar harus dipandang sebagai usaha mengembangkan seluruh pribadi siswa. Tidak hanya kemampuan kognitif saja tapi juga meliputi aspek afektif dan aspek psikomotor. Pendidikan di sekolah memiliki peran membina keimanan dan ketakwaan serta merubah watak dan kepribadian anak bangsa sesuai dengan tujuan pendidikan nasional. Selain keluarga maka karakter iman dan takwa peserta didik menjadi tanggung jawab pendidik. Masnun (2007, h, 200). Pembelajaran di sekolah saat ini sebahagian besar telah menggunakan kurikulum 2013. Konsep dasar dari kurikulum 2013 yaitu mencoba mengintegrasikan beberapa pelajaran ke dalam tema besar berdasarkan standard kompetensi yang dimiliki masing-masing pelajaran. Miftah (2017, h 18). Pentingnya penanaman nilai-nilai spiritual pada materi pelajaran ,terutama dalam meteri ilmu pengetahuan alam.

Ilmu Pengetahuan Alam (IPA) merupakan mata pelajaran yang diajarkan di SD. Menurut James Conant dalam Samatowa (2011, h 1). Semakin majunya IPTEK (Ilmu Pengetahuan dan Teknologi) pada saat ini, perubahan penemuanpenemuan yang ada pada saat ini harus dibarengi dengan penambahan keagamaan. MateriP embelajaran IPA khususnya pada Tema Reproduksi pada tumbuhan diintegarasikan dengan Ilmu-ilmu Islam berdasarkan Al-qur'an, sehingga ditemukanlah akar benang merah dari integrasi kedua kajian tersebut.

Berdasarkan hasil observasi, Guru SDN 193 Pekanbaru dan mahasiswa/calon guru tadris IPA di semester II TA 2018/2019 sering mengeluh tentang sulitnya memahami konsep-konsep IPA. Konsep IPA sains-islam yang sulit dipahami oleh calon guru, latar belakang sekolah dijadikan alasan bahwa mayoritas mahasiswa calon guru SD berasal dari IPS sehingga sulit untuk menerima materi IPA yang memerlukan pemahaman dan memiliki kesadaran untuk meyakininya secara Islam. Penguasaan konsep merupakan bagian yang sangat penting yang harus dimiliki oleh calon guru ketika mempelajari sains Reif dalam Murtono (2014, h 86). Maka dari itu peneliti ingin mengetahui seberapa besar pemahaman konsep integrasi sains-islam reproduksi pada tumbuhan Guru dan Calon guru. Untuk itu guru dan calon harus paham dengan konsep reproduksi tumbuhan baik secara sains maupun islam. Harapannya dengan adanya integrasi tersebut memudahkan siswa untuk menambah wawasan serta munculnya keyakinan iahiyyah. Sehingga telihat jelas bahwa ilmu-ilmu sains dengan ilmu agama saling melengkapi.

Pemahaman merupakan terjemahan dari istilah understanding yang diartikan sebagai penyerapan arti suatu materi yang dipelajari. Dalam Kamus Besar Bahasa Indonesia (KBBI), paham berarti mengerti dengan tepat, sedangkan konsep berarti suatu rancangan. Tim Akar Media ( 2003, h 330). Pemahaman konsep dapat diartikan sebagai proses berpikir seseorang untuk mengolah bahan belajar yang diterima sehingga menjadi bermakna Aunurrahman (2012, h 54).

Integrasi berasal dari bahasa inggris "integration" yang berarti penggabungan, keseluruhan atau kesempurnaan. Integrasi menurut Sanusi (1987, h 25) adalah suatu kesatuan yang utuh, tidak terpecah belah dan bercerai berai.Integrasi Agama dan Sains dimaknai sebagai proses penggabungan dan penyesuaian di antara unsur-unsur Agama maupun Sains, sehingga menghasilkan perpaduan dua dimensi berbeda yang kemudian memilki keserasian. Definisi lain mengenai integrasi adalah penyatuan atau penggabungan dua hal sehingga menjadi satu kesatuan yang utuh dan padu.

Pembelajaran IPA terpadu merupakan suatu konsep dapat dikatakan sebagai suatu pendekatan belajar mengajar yang melibatkan beberapa bidang 

pada Tumbuhan - Rafika Elsa Oktaviani, Zarkasih dan Rian Vebrianto

studi untuk memberikan pengalaman bermakna kepada peserta didik. Dikatakan bermakna karena dalam pengajaran terpadu, peserta didik akan mengalami konsep- konsep yang mereka pelajari melalui pengamatan langsung dan menghubungkannya dengan konsep lain yang mereka pahami Trianto (2010, h 57).

Pemahaman atau comprehension merupakan salah satu unsur psikologis dalam belajar yang mengharuskan siswa untuk mengerti secara mental makna dan aplikasi dari konsep sehingga siswa dapat memahami konsep secara menyeluruh Sadirman (2012, h 42-43).Ilmu Pengetahuan Alam (IPA) adalah "ilmu yang berhubungan dengan gejala-gejala alam dan kebendaan yang sistematis, tersusun secara teratur, berlaku secara umum, berupa kumpulan hasil observasi dan eksperimen." Nana Djumhana (2009, h 2) Kesatuan koherensi antara pembelajaran IPA dan agama teraplikasi dalam bentuk: science matter integrated with religious matter (mengintegrasikan materi pelajaran umum IPA dengan materi pelajaran pendidikan agama). Adanya nilai-nilai Islami inklusif dalam menyampaikan pembelajaran IPA atau sebaliknya religious matter integrated with science matter (mengintegrasikan materi pelajaran agama dengan mata pelajaran umum). Sanusi (1987, h 108).

Dalam Al-Qur'an Surat Al-Anbiyaa ayat 30 menjelasakan tentang integrasi.Dan apakah orangorang yang kafir tidak mengetahui bahwasanya langit dan bumi itu keduanya dahulu adalah suatu yang padu, Kemudian kami pisahkan antara keduanya. dan dari air kami jadikan segala sesuatu yang hidup. Maka mengapakah mereka tiada juga beriman? (QS. Al-Anbiya : 30).

Dari ayat tersebut dijelaskan bahwa Alqur'an tidak mempertentangkan antara sains dan agama. Banyak ayat yang menekankan manusia untuk memikirkan kejadian dialam untuk memperteguh keyakinan agamanya sehingga manusia memiliki keyakinan ilahiyyah dan buahnya yaitu Takwa kepada Allah. Dengan adanya integrasi manusia dapat mengelola alam, melakukan berbagai proses, maupun memproduksi sesuatu untuk kebutuhan.

Diperjelas lagi berdasarkan hasil penelitian Zarima dan Rian (2017, h 170) lembaga pendidikan Islam formal yang tepat dalam penyelenggaraan proses pembelajaran terpadu yaitu Sekolah yang berlatar belakang Islam. Proses pembelajaran terpadu tersebut dapat menciptakan pemahaman yang utuh oleh siswa dalam mempelajari suatu pelajaran baik dari segi keilmuan sains dan juga dari segi keilmuan Agama Islam (Al- Qur'an) untuk membentuk generasi yang Ulul Albab. Oleh karena itu, seharusnya sekolah-sekolah yang berlatar belakang Islam dapat menerapkan proses pembelajaran terpadu dengan baik.

Pentingnya integrasi dalam pembelajaran IPA disekolah Sasarannya yaitu mendidik peserta didik, dari sejak dini agar menyadari bahwa kehidupannya didunia ini menuntutnya untuk mencapai kehidupan akhirat. Prioritas yang penting dipelajari dalam menuntut ilmu yaitu memperoleh kebaikan didunia dan di akhirat. Melalui integrasi sains dengan ayat-ayat A-qur'an cita-cita tersbut terwujud. Asrorum Ni'am Sholeh (2006, h 175).

Tumbuhan merupakan salah satu makhluk hidup ciptaan Allah yang sangat bermanfaat. Tumbuhan dapat memunculkan beberapa zat untuk dimanfaatkan oleh makhluk hidup lainnya. Dalam ilmu biologi, tumbuhan mengalami proses pertumbuhan yang sangat rumit. Mulai dari perkecambahan, melakukan penyerapan air dari dalam tanah. Tumbuhan memulai perkembangannya. Semua proses dan dialami oleh tanaman mulai dari sejak awal sampai proses selanjutnya sebenarnya sudah terangkum dalam Al-qur'an. 
213 Pemahaman Konsep Guru Dan Calon Guru Tentang Integrasi Sains-Islam pada Materi Reproduksi pada Tumbuhan - Rafika Elsa Oktaviani, Zarkasih dan Rian Vebrianto

Reproduksi tumbuhan adalah suatu proses dimana tumbuhan memperoleh organisme baru yang sesuai dengan induknya. Tujuan reproduksi (berkembang biak) untuk memperbanyak keturunan sehingga tidak punah, dengan kata lain melestarikan keturunannya. Dedi dan Wawa (2007, h 295). Perkembangan makhluk hidup pada tumbuhan dengan cara vegetatif (tidak kawin) dan generatif (kawin). Vegetatif terjadi dengan cara alami dan buatan. Macam-macam perkembangbiakan secara vegetatif alami yaitu dengan cara Membelah diri, Fragmentasi, Tunas, Spora, Umbi akar, Umbi batang, Umbi Lapis, Akar tinggal, Geragih / Stolon, Stek, Cangkok. Sedangkan macam-macam perkembangbiakan vegetatif secara butan yaitu Cangkok, Setek ada dua yaitu setek batang dan setek daun, runduk, Menempel (okulasi), Sambung pucuk (mengenten).

Perkembangbiakan generatif disebut juga perkembangbiakan secara kawin (seksual), karena ditandai adanya peleburan sel kelamin jantan dan sel kelamin betina. Peleburan dua sel gamet tersebut dinamakan pembuahan. Pada tumbuhan biji tertutup, pembuahan didahului oleh penyerbukan, yaitu menempelnya serbuk sari dikepala putik. Pembuahan akan menghasilkan biji.Biji yang jatuh ditempat yang cocok dapat tumbuh menjadi individu baru. Sri Harmi (2012, 168). Perkembangbiakan generatif pada tumbuhan adalah terjadinya tumbuhan baru yang didahului dengan penyerbukan / Persarian. Penyerbukan /

Persarian merupakan peristiwa jatuhnya serbuk sari yang mengandung sel kelamin jantan ke kepala putik yang mengandung sel kelamin betina. Alat-alat perkembangbiakan generatif tumbuhan terdapat pada bunga. Bentuk dan susunan bunga setiap jenis tumbuhan berbeda-beda.

Dalam kehidupan beragama salah satu makhluk hidup yaitu tumbuhan banyak digunakan sebagai ilustrasi dalam penyampaian pesan Allah, baik dalam bentuk cerita maupun perumpamaan, hingga hal-hal yang mengarah kepada penjelasan mengenai ilmu pengetahuan. Dalam pembelajaran IPA SD Negeri, khususnya materi reproduksi tumbuhan. Penyajian dan penyampaian materi hanya disampaikan secara umum dan ilmiah, dan tidak ada mengulaas mukjizat ilmiah yang terkandung Al-quran. Maka, patutlah sekiranya dipadukan Ayat Al-qur'an tentang materi IPA reproduksi tumbuhan. Ayat-ayat Al-Qur'an yang berkaitan dengan reproduksi pada tumbuhan.

Seperti yang tercantum dalam QS. Al-fath : 29 “ Muhammad itu adalah utusan Allah dan orang-orang yang bersama dengan dia adalah keras terhadap orang-orang kafir, tetapi berkasih sayang sesama mereka. kamu lihat mereka ruku' dan sujud mencari karunia Allah dan keridhaan-Nya, tandatanda mereka tampak pada muka mereka dari bekas sujud. Demikianlah sifat-sifat mereka dalam Taurat dan sifat-sifat mereka dalam Injil, yaitu seperti tanaman yang mengeluarkan tunasnya Maka tunas itu menjadikan tanaman itu Kuat lalu menjadi besarlah dia dan tegak lurus di atas pokoknya; tanaman itu menyenangkan hati penanam-penanamnya Karena Allah hendak menjengkelkan hati orang-orang kafir (dengan kekuatan orang-orang mukmin). Allah menjanjikan kepada orang-orang yang beriman dan mengerjakan amal yang saleh di antara mereka ampunan dan pahala yang besar.”

Perkambangbiakan melalui tunas disebut sebagai vegetattif alamiTumbuhan dikatakan berkembangbiak dengan tunas apabila tunas dari tumbuhan induk tumbuh menjadi tumbuhan baru. 

pada Tumbuhan - Rafika Elsa Oktaviani, Zarkasih dan Rian Vebrianto

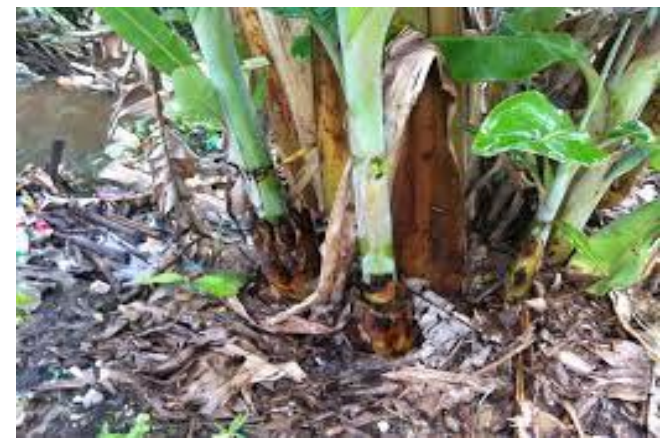

Gambar 1. Batang pisang

Perkembangbiakan melaui tunas ini disebutkan dalam Al-Qur'an tercantum dalam QS. Al-fath : 29 Contoh tumbuhan yang Berkembang biak dengan tunas adalah pisang Dedi dan Wawa (2007, h 295).

Dilihat dari tafsirnya, surat Alfath ayat 29 yaitu (Muhammad itu) adalah utusan Allah, (dan orang-orang yang bersama dengan dia) yakni para sahabatnya yang terdiri dari kaum mukminin. Lafal ayat ini menjadi Mubtada sedangkan Khabarnya ialah (adalah keras) yakni mereka adalah orang-orang yang bersikap keras (terhadap orang-orang kafir) mereka tidak mengasihaninya (tetapi berkasih sayang sesama mereka) menjadi Khabar yang kedua; yakni mereka saling kasih-mengasihi di antara sesama mukmin bagaikan kasih orang tua kepada anaknya (kamu lihat mereka) kamu perhatikan mereka (rukuk dan sujud) keduanya merupakan Hal atau kata keterangan keadaan (mencari) lafal ayat ini merupakan jumlah Isti`naf, yakni mereka melakukan demikian dalam rangka mencari (karunia Allah dan keridaan-Nya, tanda-tanda mereka) ciri-ciri mereka, lafal ayat ini menjadi Mubtada (tampak pada muka mereka). Tanda-tanda tersebut berupa nur dan sinar yang putih bersih yang menjadi ciri khas mereka kelak di akhirat, sebagai pertanda bahwa mereka orang-orang yang gemar bersujud sewaktu di dunia (dari bekas sujud.)

Lafal ayat ini berta'alluq kepada lafal yang menjadi Ta'alluq atau gantungan bagi
Khabar, yaitu lafal Kaainatan. Kemudian sebagai Hal karena mengingat. (Demikianlah) sifat-sifat yang telah disebutkan tadi (sifatsifat mereka) yakni gambaran tentang mereka, (dan sifat-sifat mereka dalam kitab Injil) adalah (yaitu seperti tanaman yang mengeluarkan tunasnya) dapat dibaca, yakni tunasnya (maka tunas itu menjadikan tanaman itu kuat) dapat dibaca Fa`aazarahuu atau Fa`azarahu, yakni tunas itu membuat tanaman menjadi kuat (lalu menjadi besarlah dia) membesarlah dia (dan tegak lurus) yakni kuat dan tegak lurus (di atas pokoknya) Saaqun (tanaman itu menyenangkan hati penanampenanamnya) karena keindahannya.

Perumpamaan ini merupakan gambaran tentang keadaan para sahabat karena mereka pada mulanya berjumlah sedikit lagi masih lemah, kemudian jumlah mereka makin bertambah banyak dan bertambah kuat dengan sistem yang sangat rapi (karena Allah hendak menjengkelkan hati orang-orang kafir dengan kekuatan orang-orang mukmin) lafal ayat ini berta'alluq kepada lafal yang tidak disebutkan yang disimpulkan dari kalimat sebelumnya, yakni mereka diserupakan demikian karena Allah hendak menjengkelkan hati orang-orang kafir (Allah menjanjikan kepada orang-orang yang beriman dan mengerjakan amal yang saleh dari kalangan mereka) yakni para sahabat; huruf Min di sini menunjukkan makna Bayanul Jinsi atau untuk menjelaskan jenis, bukan untuk menunjukkan makna Tab'idh atau sebagian, demikian itu karena para sahabat semuanya memiliki sifatsifat tersebut (ampunan dan pahala yang besar) yakni surga; kedua pahala itu berlaku pula bagi orang-orang sesudah mereka, sebagaimana yang telah dijelaskan dalam berbagai ayat lainnya. 

pada Tumbuhan - Rafika Elsa Oktaviani, Zarkasih dan Rian Vebrianto

Pada ayat Al-Qur'an yang lain dijelaskan mengenai bagaimana tumbuhan berbiji (spermatophyta) itu melakukan reproduksi atau mengawinkan tumbuh-tumbuhan dengan bantuan angin dan air yang merupakan bagian dari kekuasaan Allah. Reproduksi dengan bantuan air dan angin.

"Dan kami Telah meniupkan angin untuk mengawinkan (tumbuh-tumbuhan) dan kami turunkan hujan dari langit, lalu kami beri minum kamu dengan air itu, dan sekalikali bukanlah kamu yang menyimpannya" (QS. Al-Hijr : 22)

Abdullah Bin Muhammad, dkk (2008, h 207) wa arsalnar riyaaha lawaakiha "Dan Kami telah meniupkan angin untuk mengawinkan", maksudnya mengawinkan mendung sehingga menurunkan hujan, mengawinkan pohon-pohon dan tumbuhtumbuhan sehingga terbuka daun-daun dan bunga-bunganya. Allah menyebutnya dengan bentuk jama' untuk menunjukkan angin yang membuahi, bukan angin yang mandul, karena angin yang kedua ini sering disebutkan dengan bentuk mufrad dan disifati dengan mandul karena tidak dapat membuahi, karena pembuahan itu hanya terjadi antara dua benda "bunga jantan dan betina” atau lebih.

Firman Allah: wa maa antum lahuu bikhaaziniin "Dan sekali-sekali bukanlah kamu yang menyimpannya." Bikhaaziniin artinya bimaa ni’iin (yang mencegah air tersebut), dan ada kemungkinan artinya, bihaafidhiin (yang menjaga, yang memeliharanya). Tapi Kamilah yang menurunkannya, menjaganya untuk kalian dan menjadikannya mata air dan sumber air di bumi. Jika Allah menghendaki, pasti dijadikan-Nya mengering dan hilang. Tetapi karena kasih sayang (rahmat)-Nya, Allah menurunkannya, menjadikannya air yang segar (tawar) dan menyimpannya dalam mata air, sumur, sungai dan lain-lainnya, agar air tersebut tetap tersedia bagi mereka sepanjang tahun, sehingga mereka dapat minum dan memberi makan ternak mereka, mengairi sawah dan buah-buahan mereka.

Kelangsungan hidup pada tumbuhan secara alami memiliki dua sistem reproduksi yaitu vegetatif dan generatif. Proses reproduksi secara generatif telah disebutkan dalam Al-Qur'an surat Al-Hijr ayat 22. Dijelaskan bahwa angin berperan pada proses pengembangbiakan tumbuhan, terjadinya penyerbukan tanaman. Melalui bantuan angin yang menjatuhkan serbuk sari (sel jantan) pada bagian kepala putik (ovarium betina). Angin salah satu pengantar mempelai jantan (serbik sari) kepada mempelai betina yang bernama putik.

Dalam dunia sains, fase tersebut sisebut sebagai penyerbukan abiotik. Sebagian besar tanaman yang menjalani proses abiotik antara lain rumput, tanaman konifer, dan pohon deciduous. Namun, secara umum bagianbagian bunga yang lengkap dapat kamu lihat pada gambar berikut.

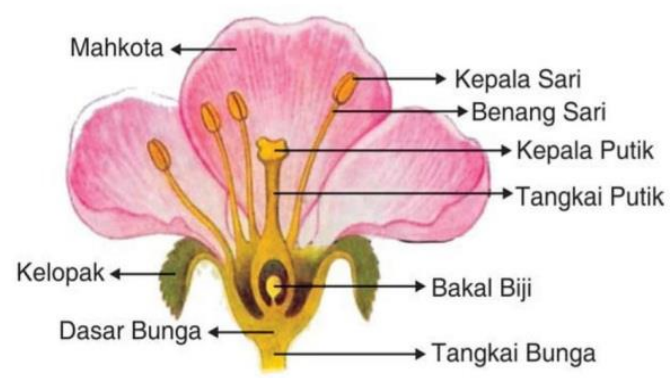

Gambar 2. Bagian Bunga

Berdasarkan asal serbuk sari, penyerbukan / Persarian dibedakan menjadi 4 ( empat ) macam, yaitu : Penyerbukan sendiri, yaitu serbuk sari jatuh ke kepala putik bunga itu sendiri. Penyerbukan tetangga, yaitu serbuk sari jatuh ke kepala putik bunga lain tetapi kedua bunga itu masih satu pohon. 
216 Pemahaman Konsep Guru Dan Calon Guru Tentang Integrasi Sains-Islam pada Materi Reproduksi pada Tumbuhan - Rafika Elsa Oktaviani, Zarkasih dan Rian Vebrianto

Penyerbukan silang, yaitu serbuk sari jatuh ke kepala putik bunga lain yang berbeda pohon tetapi masih satu jenis. Penyerbukan bastar, yaitu serbuk sari jatuh ke kepala putik bunga lain yang berbeda pohon dan tidak sejenis tetapi masih satu famili. Contoh penyerbukan antara cabe merah dengan cabe rawit. Jadi penyerbukan terjadi melalui angin, air, serangga dan burung dan hewan lainnya. Istamar Syamsuri, dkk (2004, h 15).

Sesungguhnya pengetahuan yang kita peroleh pada abad modern ini ternyata termaktub dalam Al-Qur'an. Kitab yang turun lebih dari 14 abad silam. Ramadhani $\operatorname{Dkk}(2016$, h 98).

Buah merupakan hasil proses produksi tumbuhan tingkat tinggi yang mempunyai susunan lengkap dan kompleks. Sebelum tejadi buah ada bunga yang jantan dan betina. Lalu menghasilkan buah. Buah yang sudah matang menghasilkan bji. Biji akan tumbuh dan pada bagian yang terbuka tutup luarnya akan menyerap makanan ketanah serta berkembang dan menghasilkan individu baru. Surat Al-An'aam: 95. "Sesungguhnya Allah menumbuhkan butir tumbuhtumbuhan dan biji buah-buahan. dia mengeluarkan yang hidup dari yang mati dan mengeluarkan yang mati dari yang hidup. (yang memiliki sifat-sifat) demikian ialah Allah, Maka Mengapa kamu masih berpaling?"(Q.S Al-An'aam: 95).

Penelitian ini relevan dengan penelitian Novita Cahyatul Uriyah, dkk dengan judul analisis miskonsepsi materi cara perkembangbiakan tumbuhan menggunakan certainty of response index pada siswa kelas vi sd.Berdasarkan hasil penelitian menggunakan metode CRI dapat disimpulkan bahwa miskonsepsi materi perkembangbiakan tumbuhan pada siswa kelas VI SDN Jember Kidul 02 sebesar 50,11\%. Persentase tersebut dikategorikan sedang. Novita Cahyatul Uriyah, dkk $(2018,48)$.

\section{METODE}

Penelitian ini dilaksanakan pada bulan mei 2019 di prodi Tadris IPA Fakultas Tarbiyah dan Keguruan UIN Sultan Syarif Kasim Riau dan SD Negeri 193 Pekanbaru.

Jenis penelitian ini adalah penelitian adalah survey. Menurut Arikunto (2004:310), penelitian survey hanya menggambarkan "apa adanya" tentang suatu variabel, gejala atau keadaan dan tidak dimaksudkan untuk menguji hipotesis tertentu. Penelitian deskriptif ini sesuai dengan tujuan penelitian yang ingin mengetahui pemahaman konsep Integrasi (Islam-Sains) reproduksi pada tumbuhan.

Teknik pengumpulan data yang digunakan adalah metode angket. Metode angket digunakan untuk memperoleh data pemahaman konsep guru dan calon guru. Metode angket pada penelitian ini dengan menggunakan skala Linkert. Analisis data untuk angket pemahaman konsep diukur dengan menggunakan skala likert. Cara yang digunakan untuk mencari persentase adalah menggunakan rumus 1.

$$
\frac{R}{S M}
$$

Sumber: (Purwanto, 2013 h 79)

\section{Keterangan:}

$\mathrm{NP}=$ Nilai persen yang dicari atau diharapkan

$\mathrm{R}=$ Skor mentah yang diperoleh siswa

$\mathrm{SM}=$ Skor maksimum ideal dari pernyataan yang bersangkutan

Hasil analisis dikonversikan sehingga diketahui kriteria nilai pemahaman konsep guru dan calon guru yaitu pada tabel 1 . 
217 Pemahaman Konsep Guru Dan Calon Guru Tentang Integrasi Sains-Islam pada Materi Reproduksi pada Tumbuhan - Rafika Elsa Oktaviani, Zarkasih dan Rian Vebrianto

Tabel 1. Kriteria Pemahaman Konsep

\begin{tabular}{|l|l|}
\hline \multicolumn{1}{|c|}{ Angka } & Keterangan \\
\hline $0 \% \leq \mathrm{S}<40 \%$ & Sangat rendah \\
\hline $40 \% \leq \mathrm{S}<55 \%$ & Rendah \\
\hline $55 \% \leq \mathrm{S}<70 \%$ & Sedang \\
\hline $70 \% \leq \mathrm{S}<85 \%$ & Tinggi \\
\hline $85 \% \leq \mathrm{S} \leq 100 \%$ & Sangat tinggi \\
\hline
\end{tabular}

Sumber: (Mawaddah, 2016, 95)

\section{HASIL DAN PEMBAHASAN}

Pemahaman guru dan calon guru tantang konsep integrasi (Sains-islam) Reproduksi pada tumbuhan, diberikan dengan memberikan angket skala likert dengan lima skala yaitu STS (Sangat tidak setuju), KS (Kurang setuju), TT (Tidak tahu / netral), S (Setuju), SS (Sangat setuju) dengan 15 item pertanyaan. Lembar angket disusun berdasarkan indikator konsep sains-islam reproduksi pada tumbuhan. Yang terdiri dari pernyataan yang positif dan pernyataan yang negatif. Berikut ini tabel yang memuat pernyataan positif dan negatif.

Tabel. 2 Pernyataan positif dan negatif

\begin{tabular}{|l|l|}
\hline \multicolumn{2}{|c|}{ PERNYATAAN } \\
\hline \multicolumn{1}{|c|}{$\begin{array}{c}\text { Favorable } \\
\text { (positif) }\end{array}$} & $\begin{array}{c}\text { Unfavorable } \\
\text { (Negatif) }\end{array}$ \\
\hline $\begin{array}{l}\text { Pernyataan 1, 2, 5, } \\
6,8,9,10,11,12,\end{array}$ & $\begin{array}{l}\text { Pernyataan 3, 4, } \\
13,14\end{array}$ \\
\hline
\end{tabular}

Dalam 15 item pernyataan yang disajikan dalam angket tidak hanya berupa pernyataan yang positif (Favorable) dan pernyataan negatif (unfavorable). Tetapi peneliti juga menyajikan pernyataan konsep reproduksi pada tumbuhan dalam konsep sains dan konsep islam. Pada tabel 3 memuat pernyataan dengan konsep sains dan konsep islam.

Konsep sains reproduksi pada tumbuhan termuat dalam pernyataan 3 Tumbuhan berkembang hanya dengan cara vegetatif, ini merupakan pernyataan negatif. Pernyataan 5 Tumbuhan paku berkembang biak melalui spora, ini pernyataan postif. Penyerbukan silang merupakan reproduksi generatif, pernyataan positif ini terdapat dalam pernyataan 6. Pernyataan 8 (positif) yaitu Tumbuhan tingkat rendah seperti ganggang berkembang biak dengan membelah diri. Pernyataan 9 (positif) adalah Tumbuhan yang berkembang biak dengan akar tinggal adalah jahe, lengkuas, temulawak, kunyit, dan rumput. Bawang merupakan Tumbuhan yang berkembangbiak dengan umbi lapis. Umbi lapis perkembangbiakan secara vegetatif, ini merupakan peryataan positif yang terdalam dalam pernyataan 10 .

Pernyataan 11 (positif) Akar yang berubah fungsi untuk menyimpan cadangan makanan disebut umbi batang. Pernyataan 12 (positif) Batang yang tumbuh menjalar diatas atau dibawah permukaan tanah disebut geragih. Tunas pada buku-buku batang dapat tumbuh menjadi tumbuhan baru. Pernyataan 13 (positif) Cocor bebek berkembangbiak melalui tunas adventif. Pernyataan 14 (positif) Reproduksi bunga melati terjadi dengan bantuan manusia yaitu dengan cara merunduk. Batangtumbuhanyang dicangkok lebih kokoh dan tahan lama bertahun-tahun, ini merupakan positif yang terdapat dalam pernyataan 5.

Selanjutnya konsep islam reproduksi pada tumbuhan terdapata pada pernyataan 1Reproduksi Tumbuhan jagung perkembangbiakannya melalui angin. Dalam islam terdapat pada surat Al-Hijr ayat 22, ini merupakan pernyataan positif. Pernyataan 2 (positif) yaitu Pada surat Al-Fath ayat 29 disebutkan Tumbuhan pisang berkembang biak dengan cara tunas.Pernyataan 4 (negatif) yaitu mangga tumbuh melalui biji tanpa ada penyerbukan. Tumbuh melalui biji telah dicantumkan dalam Al-qur' an surat Al-An'an ayat 95.Al-qur'an surat Al-Hijr ayat 22 menyebutkan Serbuk sari jatuh ke kepala putik bunga itu sendiri, ini merupakan pernyataan (negatif) terdapat dalam pernyataan 7 . 
218 Pemahaman Konsep Guru Dan Calon Guru Tentang Integrasi Sains-Islam pada Materi Reproduksi pada Tumbuhan - Rafika Elsa Oktaviani, Zarkasih dan Rian Vebrianto

Berdasarkan data yang diperoleh melalui jawaban angket yang telah dikerjakan masingmasing guru dan calon guru diperoleh hasil seperti tersaji pada tabel hasil pemahaman konsep sainsislam reproduksi pada tumbuhan yang ditunjukkan pada tabel 4 sebagai berikut.

Tabel 4. Hasil Pemahaman Konsep sains-islam reproduksi pada tumbuhan Berdasarkan Angket

\begin{tabular}{|c|c|c|c|c|c|c|c|c|c|c|}
\hline No & Pernyataan & $\begin{array}{c}\text { Jumlah } \\
\text { Responden }\end{array}$ & STS & ST & TT & $\mathbf{S}$ & SS & $\begin{array}{l}\text { Nilai Rata- } \\
\text { rata Hasil } \\
\text { Quesioner }\end{array}$ & $\begin{array}{c}\text { Persentase } \\
\text { pemahaman } \\
\text { konsep }\end{array}$ & Kategori \\
\hline 1. & $\mathrm{P} 1$ & 30 & 0 & 0 & 2 & 8 & 20 & 4,5 & 90,6 & $\begin{array}{l}\text { Sangat } \\
\text { Tinggi }\end{array}$ \\
\hline 2. & $\mathrm{P} 2$ & 30 & 1 & 1 & 1 & 10 & 17 & 4,4 & 87,3 & $\begin{array}{l}\text { Sangat } \\
\text { Tinggi }\end{array}$ \\
\hline 3. & P3 & 30 & 0 & 0 & 9 & 9 & 12 & 3,9 & 78,0 & Tinggi \\
\hline 4. & $\mathrm{P} 4$ & 30 & 5 & 2 & 2 & 11 & 10 & 2,4 & 47,3 & Rendah \\
\hline 5. & P5 & 30 & 10 & 18 & 2 & 0 & 0 & 4,3 & 85,3 & $\begin{array}{l}\text { Sangat } \\
\text { Tinggi }\end{array}$ \\
\hline 6. & P6 & 30 & 0 & 0 & 3 & 20 & 7 & 4,1 & 82,6 & Tinggi \\
\hline 7. & P7 & 30 & 3 & 6 & 4 & 8 & 9 & 2,5 & 50,6 & Rendah \\
\hline 8. & P8 & 30 & 1 & 2 & 11 & 10 & 6 & 3,6 & 72,0 & Tinggi \\
\hline 9. & P9 & 30 & 1 & 1 & 10 & 11 & 7 & 3,7 & 74,6 & Tinggi \\
\hline 10 & P10 & 30 & 0 & 0 & 1 & 23 & 6 & 4,2 & 83,3 & Tinggi \\
\hline 11 & P11 & 30 & 5 & 2 & 3 & 14 & 6 & 3,5 & 69,3 & Sedang \\
\hline 12 & P12 & 30 & 0 & 2 & 5 & 16 & 7 & 3,9 & 78,6 & Tinggi \\
\hline 13 & P13 & 30 & 0 & 2 & 2 & 16 & 10 & 4,1 & 82,6 & Tinggi \\
\hline 14 & P14 & 30 & 0 & 4 & 10 & 15 & 1 & 3,4 & 68,8 & Sedang \\
\hline 15 & P15 & 30 & 1 & 7 & 2 & 15 & 5 & 2,5 & 50,0 & Rendah \\
\hline \multicolumn{3}{|c|}{ Total } & 27 & 47 & 67 & $6^{18}$ & 123 & \multirow[t]{2}{*}{3,7} & \multirow[t]{2}{*}{73,4} & \multirow[t]{2}{*}{ Tinggi } \\
\hline \multicolumn{8}{|c|}{ Rata-rata } & & & \\
\hline
\end{tabular}

Berdasarkan Tabel 4 nilai rata-rata hasil quesioner secara keseluruhan yaitu 3,7, sebesar 
219 Pemahaman Konsep Guru Dan Calon Guru Tentang Integrasi Sains-Islam pada Materi Reproduksi pada Tumbuhan - Rafika Elsa Oktaviani, Zarkasih dan Rian Vebrianto

$73,4 \%$, pemahaman konsep guru dan calon guru

tumbuhan kategorinya tinggi.

pada konsep sains-islam reproduksi pada

Tabel. 5 Hasil Pemahaman Konsep Sains -Islam IPA

\begin{tabular}{|l|l|l|l|l|l|}
\hline No & Konsep & $\begin{array}{l}\text { Jumlah } \\
\text { Responden }\end{array}$ & $\begin{array}{l}\text { Nilai Rata- } \\
\text { Rata Hasil } \\
\text { Quesioner }\end{array}$ & $\begin{array}{l}\text { Persentase } \\
\text { Pemahaman } \\
\text { Konsep }\end{array}$ & Kategori \\
\hline 1 & Sains & 30 & 3,7 & 74,9 & Tinggi \\
\hline 2 & Islam & 30 & 3,5 & 69,0 & Sedang \\
\hline
\end{tabular}

Reproduksi tumbuhan adalah suatu proses

Berdasarkan hasil perhitungan akhir ratarata pemahaman konsep pada tabel. 5 setelah diberikan pernyataan dalam bentuk angket pemahaman konsep sains reproduksi pada tumbuhan sebesar 74,9\% dengan kategori tinggi. Sedangkan pemahaman konsep Islamnya sebesar $69 \%$ dengan kategori sedang. Secara umum persentase pemahaman guru dan calon guru pada konsep sains lebih besar (74,9\%) dari pada konsep islam. Sehingga dapat diketahui pemahaman guru dan calon guru tentang konsep reproduksi tumbuhan secara sains lebih baik dari pada konsep reproduksi tumbuhan secara islam. Lebih jelas lagi lihat pada tabel hasil dipernyataan 4 rata-rata hasil quesioner 2,4 dan persentase 47,3. dipernyataan 7 rata-rata hasil quesioner 2,5 dan persentase 50,6. Pernyataan 4 dan pernyataan 7 merupakan konsep islam, pemahaman konsep islam terkategori rendah.

\section{SIMPULAN}

Semakin majunya IPTEK (Ilmu Pengetahuan dan Teknologi) pada saat ini, perubahan penemuan-penemuan yang ada pada saat ini harus dibarengi dengan penambahan keagamaan. Materi Pembelajaran IPA khususnya pada Tema Reproduksi pada tumbuhan diintegarasikan dengan Ilmu-ilmu islam berdasarkan Al-qur'an, sehingga ditemukanlah akar benang merah dari integrasi kedua kajian tersebut. tumbuhan memperoleh organisme baru yang sesuai dengan induknya. Secara sains reproduksi pada tumbuhan terjadi secara vegetatif (tidak kawin) dan generatif (kawin). Konsep vegatatif alami, tumbuhan pisang berkembangbiak denga tunas. Konsep tersebut sudah dijelaskan didalam al-qur'an surat Al-fath ayat 29. Perkembangbiakan generatif (kawin) melalui angin dijelaskan dalam Al-Qur'an Surat Al-Hijr ayat 22. perkembangbiakan melaui biji disebutkan daam alQur'an Surat Al-An'aam: 9.

Setelah angket konsep Integrasi (SainsIslam) reproduksi pada tumbuhan, dan Hasil Pemahaman konsep sains-islam guru dan calon guru manunjukkan kategori tinggi,nilai rata-rata hasil quesioner secara keseluruhan yaitu 3,7, sebesar $73,4 \%$. pemahaman konsep guru dan calon guru pada konsep sains-islam reproduksi pada tumbuhan kategorinya tinggi. Hasil perhitungan akhir rata-rata pemahaman konsep sains reproduksi pada tumbuhan sebesar 74,9\% dengan kategori tinggi. Sedangkan pemahaman konsep Islamnya sebesar 69\% dengan kategori sedang. Secara umum persentase pemahaman guru dan calon guru pada konsep sains lebih besar $(74,9 \%)$ dari pada konsep islam (69\%). Sehingga dapat diketahui pemahaman guru dan calon guru tentang konsep reproduksi tumbuhan secara sains lebih baik dari pada konsep reproduksi tumbuhan secara islam. 
220 Pemahaman Konsep Guru Dan Calon Guru Tentang Integrasi Sains-Islam pada Materi Reproduksi pada Tumbuhan - Rafika Elsa Oktaviani, Zarkasih dan Rian Vebrianto

\section{DAFTAR PUSTAKA}

Arikunto, (2004) Prosedur Penelitian Suatu Pendekatan Praktek, (Jakarta: Rineka Cipta)

Asrorun Ni'am Sholeh. (2006). Reorientasi Pendidikan Islam. Jakarta: Elsas

Aunurrahman, (2012). Belajar dan Pembelajaran. Bandung Alfabeta.

Dedi M. Rachmandan Wawa Wibawa. (2007) Inti Sari Biologi. Bandung: PustakaSetia.

Abdullah Bin Muhammad, dkk. (2008). TafsirIbnuKatsirjilid 7. Jakarta :Pustaka Imam Syafi'i.

Istamar Syamsuri, Dkk. (2004). Sains Biologi SMP. Jakarta: Erlangga

Mawaddah, S. (2016). Kemampuan Pemahaman Konsep Matematis Siswa SMP Dalam Pembelajaran Menggunakan Model Penemuan Terbimbing (Discovery Learning). Jurnal Pendidikan Matematika Sebenarnya, 76-85.

Murtono, dkk, (2014). Fungsi Representasi dalam Mengakses Penguasaan Konsep Fisika, JRKPF, vol. 1, no. 2, hlm. 80-84.

Nana Djumhana, (2009). Pembelajaran Ilmu Pengetahuan Alam. Jakarta: Dirjen Pendis Depag RI

Novita Cahyatul Uriyah. Nuriman. Fajar Surya Hutama. JURNAL JPSD Vol. 4 No. 2 Tahun 2018 ISSN 2356-3869 (Print), 2614-0136 (Online)

Purwanto. (2013). Prinsip-prinsip dan Teknik Evaluasi Pengajaran. Bandung: Rosdakarya

Ramadhani Dkk, (2016). Al-Qur'an vssains modern menurut Zakir Naik. Jakarta :Sketsa

Sri Harmi. (2012). IPA Kelas VI SD. Solo: PT Tiga Serangkai

Tim Akar Media. (2003). Kamus Lengkap Praktis Bahasa Indonesia. Surabaya: Akar Media

Usman Somatowa. (2010). Pembelajran IPA di Sekolah Dasar. Jakarta: Indeks

Wina Sanjaya. (2011). Strategi Pemebalajaran Berorientasi Standar Proses Pendidikan. Jakarta, Kencana Prenada Media: 2011

Zarima Zain dan Rian Vebrianto. Integrasi Keilmuan Sains Dan Islam Dalam Proses Pembelajaran Rumpun IPA. Seminar Nasional Teknologi Informasi, Komunikasi dan Industri (SNTIKI) 9 ISSN (Printed) :
2579-7271 Fakultas Sains dan Teknologi, UIN Sultan Syarif Kasim Riau ISSN (Online) : 2579-5406 Pekanbaru, 18-19 Mei 2017 